кандидат педагогічних наук, доцент

(Житомирський державний університет імені Івана Франка) wlasolia@gmail.com

ORCID: $0000-0001-7258-2108$

\title{
ПРОБЛЕМА ГРОМАДЯНСЬКИХ ЦІННОСТЕЙ ОСОБИСТОСТІ В КОНТЕКСТІ ЗАРУБІЖНИХ КОНЦЕПЦИЙ ГРОМАДЯНСЬКОГО СУСПІЛЬСТВА
}

У статті розглянуті сучасні підходи до визначення поняття "громадянськість", "громадянське суспільство", "громадянські иінності"; виділені основні ознаки глобального громадянського суспільства. Автор досліджує теоретичні погляди зарубіжних вчених з проблеми громадянськості, системи громадянських иінностей в науковій літературі, визначає характерні особливості різних зарубіжних наукових конщепџій в контексті проблематики дослідження, визначає иляхи реалізації громадянських цінностей в сучасній освіті. Автор зазначає, щзо в даний час загальновизнаною є необхідність громадянського виховання молоді, розробки єдиної державної політики в галузі громадянської освіти та виховання, загальнонаціональної мети й громадянської ідеологї, які могли б консолідувати украӥнське суспільство на основі загальнонаціональних і громадянських ијнностей.

Ключові слова: громадянське суспільство, громадянськість, громадянська освіта, громадянське виховання, ијінності, громадянські ијінності, старшокласники, освітній заклад.

Постановка проблеми у загальному вигляді. Актуальність дослідження громадянських цінностей обумовлена соціально-економічними й політичними перетвореннями, що відбуваються в Україні. Для успішної реалізації українського соціокультурного проекту необхідним є високий рівень сформованості громадянських цінностей у молоді. Громадянське суспільство сьогодні розглядають як систему суспільних інтересів (економічних, соціальних, культурних тощо), яка виражає різноманітні цінності, інтереси й потреби членів суспільства. Протягом останніх десятиліть проблема громадянських цінностей стала основним пріоритетом в освітніх дослідженнях. Це підтверджується тим, що все більше закладів освіти вводять теми громадянських цінностей як при викладанні предметів, так і в процес виховної роботи.

Аналіз останніх досліджень і публікацій. Проблема системи громадянських цінностей, громадянськості, глобального громадянства розкрито у ряді досліджень зарубіжних науковців - С. Бок, Б. Боуден, Х. Булл, Л. Девіес, Д. Ікеда, М. Едвардс, М. Кальберг, Дж. Кін, Р. Крабтрі, К. Лім, М. МакКензі, Р. Манк, Х. Шаттл, Я. Шольте, Л. Шульц та ін.

Мета статті полягає у визначенні основних ідей формування громадянських цінностей особистості в зарубіжних освітніх теоріях та концепціях.

Виклад основного матеріалу дослідження. Кінець ХX століття часто називають добою глобалізації. I хоча існують численні дискусії, як саме відбувається глобалізація, проте загально прийнятим $є$ факт, що глобалізації характерна еволюція націоналізму, тому економічні, соціальні й політичні сили намагаються усереднити "світ", оскільки вільний потік торгівлі, капіталу та інформації щомиті робить нас більш обізнаними та стійкішими, ніж будь-коли раніше [1]. Глобалізація викликала низку як позитивних змін від демократизації, поширення інформації про права людини до збільшення потоків інформації, так і негативних тенденцій - загострення глобальних проблем. Саме тому, зазначає Д. Ікеда, глобалізація "є контрастом світла і темряви" [2: IX].

Громадянське суспільство - це об'єднання людей, які мають спільні цінності й уявлення про спосіб й стиль життя. Громадянське суспільство є системою відносин, свідомості й діяльності, що створюють передумови для самореалізації індивідів, соціальних груп, окремих націй та держав, людства в цілому. Відповідно, становлення громадянського суспільства розглядається як створення середовища, в якому формується громадська думка та система громадянських цінностей (Ю. Габермас) [3: 41].

У 2000 році Комісія ООН з питань освіти, науки й культури в ХХІ столітті, визначила місію освіти в чотирьох ключових напрямках - навчання теорії й практики, життя в цілому й життя з іншими людьми. Проте, як зазначає М. МакКензі, сучасні парадигми освіти тяжіють лише до набуття знань [4], і це чітко продемонстровано скороченням освітніх програм і зростаючою залежністю від іспитів й тестів, які використовуються в якості методів оцінювання якості освіти. М. Маккензі переконаний, що на сучасні проблеми суспільства - бідність, війна, забруднення навколишнього середовища, пандемії - вплинуло нехтування трьома іншими ключовими напрямками в освіті, які спрямовані на пропаганду гуманістичних ідеалів й цілей. Науковці Х. Шаттл, Л. Шульц, М. МакКензі зазначають, що така гуманістична сторона освіти може сприяти усвідомленню відповідальності перед планетою, формуватиме активну турботу й співпереживання іншим людям як у власній країні, так і й в усьому світі $[4 ; 5 ; 6]$. 
Проблема громадянськості, громадянських цінностей, участі кожного у глобальному суспільстві безпосередньо пов'язана з концепцією глобального громадянства, яка все частіше використовується як в суспільному житті, так і в освітній сфері, оскільки все більша кількість освітніх закладів від початкової ланки до університетського рівня переконує, що сприяють формуванню громадянськості та системи громадянських цінностей у своїх учнів.

Проте, як це не парадоксально, але чіткі визначення понять "громадянськість", "громадянські цінності" зустрічаються досить рідко, оскільки концепція громадянства має багато "відтінків" [8: 14]. Зарубіжні науковці переважно виділяють три підходи до громадянськості - неоліберальний громадянин, основною метою якого є підвищення транснаціональної мобільності знань й навичок; радикальний громадянин, мета якого - руйнувати домінуючі суспільні структури; і трансформаційний громадянин, який виступає за соціальну справедливість, проти бідності, гноблення і маргіналізації [5].

Загальною думкою зарубіжних науковців $є$ думка про глобальне громадянство, яке передбачає формування у молоді знань, умінь та навичок, системи громадянських цінностей, необхідних для реагування на зростаючу кількість соціальних, політичних, економічних та екологічних проблем як країни, так і світу [9; 10]. Тому часто в зарубіжних працях громадянські цінності ототожнюються 3 гуманістичними або загальнолюдськими цінностями $[11 ; 12]$, які, крім конкретних вартостей, включають емпатію, обдарованість, захист навколишнього середовища, соціальну справедливість, прагнення бути ефективним громадянином у суспільстві, двигуном змін, а не просто пасивним спостерігачем суспільних та світових подій, спонукаючи молодь замислюватися про своє призначення в житті [13].

Держава та суспільство не повинні недооцінювати роль освіти у вихованні в свідомості людей громадянських цінностей - патріотизму, поваги до прав людини, толерантності, рівності, справедливості тощо. Однак, як і при визначенні понять громадянськості, громадянських цінностей, громадянського суспільства, не було досягнуто наукового консенсусу щодо ефективних освітніх програм для формування громадянських цінностей. Багато в чому це пов'язано з відсутністю оцінки ефективності використання різноманітних форм, методів й засобів в процесі формування громадянських цінностей молоді в освітньому середовищі навчального закладу.

Звідси постає дилема - стратегії й цінності громадянства повинні бути інтегровані в освітнє середовище загальноосвітнього закладу [10; 14], тому що стратегії формування громадянськості та громадянських цінностей не повинні виступати в якості "доповнень" до освітньої програми освітнього закладу, а, навпаки, повинні укорінюватися в статут школи, забезпечувати трансформацію культури й життя школи. Іншими словами, за умови підготовки школярів освітніх закладів в контексті ідей соціальної справедливості та рівності, турботи і співчуття, гуманізму, толерантності, патріотизму, майбутні випускники освітніх закладів, ймовірно, будуть сприймати світ по-іншому [15].

Опоненти ідеї глобального громадянства припускають, що це явище скоріше характеризує прагнення до майбутнього, а не до реальності [16: 164], це метафора, поняття, яке не може існувати, оскільки ми не можемо бути громадянами світу, ми є громадянами своєї країни, відносимося до певної нації, дотримуємося прав та обов'язків цієї нації відповідно до закону, тому обов'язки громадян суспільства нерозривно пов'язані з відносинами між громадянами й державою [17]. Крім того, існування глобального громадянства вимагає певної форми державного або світового управління. Іншими словами, саме поняття громадянськості за межами національної держави заперечується його критиками і як можливе, i як бажане явище. Заперечуючи ці аргументи, науковці говорять про появу транснаціональних структур й транснаціональних інститутів управління, таких як ООН та Європейський союз, які можуть руйнувати силу національної держави. Натомість прихильники формування глобальних громадянських цінностей стверджують, що все більше й більше людей починають ідентифікувати себе як громадяни світу 3 обов'язками, які виходять далеко за межі їх нації [14: 33].

В процесі аналізу дискусії зарубіжних науковців щодо проблеми формування громадянських цінностей в освіті, цікавим для нас є ставлення до "глобальних" або "універсальних" цінностей, оскільки ці цінності впливають на освітні програми багатьох навчальних закладів. Зокрема Б. Бауден зауважує, що нав'язування глобальних цінностей є спробою прищеплення однієї конкретної культури решті світу, що призведе до руйнування культур i, в кінцевому результаті, до культурного імперіалізму [17]. Але Н. Дауер [18] заперечує цю позицію, оскільки ідея універсальних цінностей не обов'язково означає цінності, які є "загальноприйнятими", скоріше цінності, які "повинні бути прийняті" [18: 126]. Синтез цих суперечливих думок найкраще відображено в Загальній декларації прав людини - "люди народжуються вільними і рівними у своїй гідності та правах; кожна людина повинна мати всі права і всі свободи, незалежно від раси, кольору шкіри, статі, мови, релігії, політичних або інших переконань, національного чи соціального походження, майнового, станового або іншого становища; кожна людина має право на свободу думки, совісті і релігії; кожна людина має право на свободу переконань і на вільне їх виявлення тощо". Загальна декларація прав людини дає чіткі вказівки щодо стандартів життя, прав окремих осіб, відмінностей між людьми й культурними групами. Тому саме ці права повинні бути покладені в основу громадянської освіти й формування системи громадянських цінностей молодої людини. 
Оксфам визначає ключові елементи громадянськості: знання (соціальне правосуддя, рівність, глобалізація, сталий розвиток, мир та конфлікт); уміння й навички (критичне мислення, вміння ефективно дискутувати, протистояти несправедливості й нерівності, повага до людей й речей, співпраця); цінності й ставлення (почуття власної гідності, самооцінка, емпатія, участь у соціальній справедливості та рівності, захист навколишнього середовища тощо). Концепція формування громадянськості і громадянських цінностей Оксфама підкреслює важливість навколишнього середовища і сталого розвитку, а також відзначає цінність таких якостей, як почуття власної гідності й почуття національної ідентичності [10: 7].

Відповідно до концепції формування громадянськості і громадянських цінностей Б. Бетса, ключовими елементами громадянськості є: знання (економічні, політичні, соціальні, духовні особливості суспільства, проблеми навколишнього середовища, етика); уміння (консультувати, вирішувати проблеми в команді, служити іншим, протистояти несправедливості й нерівності, бути посередником при вирішення проблем, мати здатність до інновацій, мислити й планувати складні системи, бачити проблему 3 кількох точок зору); цінності (емпатія, моральність, обурення соціальною несправедливістю, бажання жертвувати заради загального блага, бажання діяти для поліпшення світу). Слід зазначити, що Б. Беттс пропонує орієнтуватися на активність особистості, яка буде проявлятися у готовності діяти морально, щоб поліпшити світ [19].

Враховуючи вище сказане та не зважаючи на відсутність єдиної думки як щодо поняття "громадянські цінності", "громадянськість", так і якими знаннями, уміннями, навичками та цінностями повинен володіти громадянин суспільства, серед науковців, викладачів та вчителів постає питання, яку роль освітні заклади відіграють для формування громадянських цінностей молоді.

Якщо концепції зарубіжної освіти в минулих роках орієнтувалися на освіту про громадянство (наприклад, історія конституцій, політичних інститутів) 3 метою підготовки політично освічених громадян, то сьогодні освіта підкреслює необхідність заохочення активних громадян зі сформованою системою громадянських цінностей брати участь в політичних, економічних, соціальних та екологічних проблемах суспільства і світу. Освітній заклад повинен створити для молодих людей можливості вчитися й виконувати свої обов'язки перед людством і світом, таким чином підготувати їх до проблем суспільства, з якими вони будуть зустрічатися зараз і в майбутньому - бідність, соціальна нерівність, доступ до охорони здоров'я, освіти й технологій, глобальне потепління, нераціональний видобуток корисних копалин тощо.

Важливо зазначити, що як прихильники глобального громадянства, так і їх опоненти розглядають освіту як швидке вирішення соціальних проблем, які посилюються глобалізацією, освіта визнана, можливо, найповільнішим чинником соціальних змін, але єдиним ефективним. У зв'язку з цим дослідження старшокласників освітнього закладу як резерву інтелектуальної еліти, а освітнього закладу як шляху його формування набуває особливого наукового й практичного значення в умовах сучасних змін в Україні.

Вирішення цієї складної проблеми і відповідальність за формування громадянськості та системи громадянських цінностей молоді покладається суспільством на освітній заклад, який повинен створювати сприятливі умови для оволодіння учнями знаннями, уміннями та навичками, розвитку їх компетенцій та формування системи цінностей.

Висновки дослідження і перспективи подальших розвідок у вказаному напрямі. Процес становлення громадянського суспільства в Україні $\epsilon$ складним і суперечливим, тому важливим $\epsilon$ не тільки набуття власного досвіду формування громадянськості молодого покоління, але й використання ідей, концепцій зарубіжних науковців, тому що для того, щоб сформувати систему громадянських цінностей особистості, необхідно розуміння світових та локальних процесів й тенденцій розвитку сучасного громадянського суспільства. Загальна середня освіта формує громадянські цінності, які трансформуються у конкретні ціннісні уявлення та орієнтації, а освітні установи виводять школяра на новий рівень, вводять у світ культури, в освітньому процесі передають знання про громадянські цінності, формують вміння й навички, ціннісні уявлення про світ.

\section{СПИСОК ВИКОРИСТАНИХ ДЖЕРЕЛ ТА ЛІТЕРАТУРИ}

1. Friedman T. The World is Flat : A Brief History of the Twenty-First Century / T. Friedman. - Vancouver. - Douglas and McIntyre Ltd., 2007.

2. Ikeda D. Thoughts on Education for Global Citizenship. Speech presented at Teachers College / D. Ikeda. - New York. - Columbia University, 1996. - Retrieved from : http://www.daisakuikeda.org/sub/resources/works/lect/lect08.html

3. Корнієнко В.О. Політичний ідеал : проблеми еволюції та втілення в умовах сучасного суспільного розвитку : автореф. дис. ... докт. політ. наук: спец. 23.00.03 "Політична культура та ідеологія"/ Корнієнко Валерій Олександрович. - К., 2002. - 36 с. 
4. McKenzie M. The Global Schoolhouse / M. McKenzie. - Independent School, 2004. - 63 (3). - Pp. 10-85. Retrieved from: http://vnweb.hwwilsonweb.com.myaccess.library.utoronto.ca/hww/jumpstart.jhtml?recid= 0bc05f7a67b1790e7bf10c279ef10e1e91c2dabf6db08da0db5a99336a1b612e26c55a8f0a0d 7b9b\&fmt=H.

5. Shultz L. Educating for Global Citizenship : Conflicting Agendas and Understandings / L. Shultz. - Alberta Journal of Educational Research. - 2007. - 53 (3) - Pp. 248-258. - Retrieved from : http://www.education.ualberta.ca/educ/journals/ajer/53\%20files/53(3)files/53(3).html.

6. Schattle H. Global Citizenship in Theory and Practice / H. Schattle. [The Handbook of Practice and Research in Study Abroad : Higher Education and the quest for Global Citizenship]. - New York. - 2009. - Pp. 5-20.

7. Галактіонова I. В. Фактор освіти у формуванні політичної культури громадянина демократичної держави / I. В. Галактіонов // Громадянська освіта в Україні : досвід, пошуки, перспективи : матеріали конференції ; П. П. Моціяка, О. В. Желіба. - Ніжин : НДПУ, 2002. - С. 23-26.

8. Goodreau J. Exploring the Dimensions of Global Citizenship / J. Goodreau, D. Holland, \& D. Montemurro. - 2004. - Retrieved from : http://cide.oise.utoronto.ca/projects/globalcitizenship/chap1.pdf.

9. Davies L. Global Citizenship : Abstraction of Framework for Action? Educational Review / L. Davies. - 2006. 58 (1). - Pp. 5-25.

10. Oxfam. Education for Global Citizenship: A Guide for Schools [Oxfam Development Education]. - Oxford, 2006.

11. Crabtree R. D. Theoretical Foundations for International Service-learning / R. D. Crabtree // Michigan Journal of Community Service Learning. - 2008. - 15 (1). $\quad$ - Pp. 18-36. - Retrieved from: http://quod.lib.umich.edu.myaccess.library.utoronto.ca/m/mjcsl/browse.html.

12. Bok S. Common Values / S. Bok. - Columbia, USA (University of Missouri Press), 2002.

13. Lim C.P. Global Citizenship Education, School Curriculum and Games : Learning Mathematics, English and Science as a Global Citizen / C. P. Lim // Computers \& Education. - 2008. - 51 (3). - Pp. 1073-1093.

14. Munck R. Civic Engagement and Global Citizenship in a University Context: Core Business or Desirable add-on? / R. Munck // Arts and Humanities in Higher Education : An International Journal of Theory, Research and Practice. 2010. - 9 (1). - Pp.31-41.

15. Karlberg M. Discourse, Identity, and Global Citizenship / R. Munck // Peace Review. - 2010. - 20(3). - Pp. 310320.

16. Mayo M. Learning Global Citizenship? Exploring Connections Between the Local and the Global. Education, Citizenship and Social justice / M. Mayo, J. Gaventa, A. Rooke. - 2009. - 4 (2). - Pp. 161-175.

17. Bowden B. The Perils of Global Citizenship. Citizenship Studies / B. Bowden. - 2003. - 7 (3). - Pp. 349-362.

18. Dower N. An Introduction to Global Citizenship / N. Dower. - Edinburgh : Edinburgh University Press, 2003.

19. Betts B. The Challenge of Global Citizenship in Our Schools / B. Betts, 2003. - Retrieved from : http://www.theptc.org/resources/archives.html.

\section{REFERENCES (TRANSLATED \& TRANSLITERATED)}

1. Friedman T. The World is Flat : A Brief History of the Twenty-First Century / T. Friedman. - Vancouver. - Douglas and McIntyre Ltd., 2007.

2. Ikeda D. Thoughts on Education for Global Citizenship. Speech presented at Teachers College / D. Ikeda. - New York. - Columbia University, 1996. - Retrieved from : http://www.daisakuikeda.org/sub/resources/works/lect/lect08.html.

3. Korniienko V. O. Politychnyi ideal : problemy evoliutsii ta vtilennia v umovakh suchasnogo suspil'nogo rozvytku [Political Ideal : Evolution Problems and Its Introduction in Terms of Modern Social Development] : avtoref. dys. ... dokt. polit. nauk : spets. 23.00.03 "Politychna kul'tura ta ideologiia" / Korniienko Valerii Oleksandrovych. - K., 2002. $-36 \mathrm{~s}$.

4. McKenzie M. The Global Schoolhouse / M. McKenzie. - Independent School, 2004. - 63 (3). - Pp. 10-85. Retrieved from: http://vnweb.hwwilsonweb.com.myaccess.library.utoronto.ca/hww/jumpstart.jhtml?recid= 0bc05f7a67b1790e7bf10c279ef10e1e91c2dabf6db08da0db5a99336a1b612e26c55a8f0a0d 7b9b\&fmt=H.

5. Shultz L. Educating for Global Citizenship : Conflicting Agendas and Understandings / L. Shultz. - Alberta Journal of Educational Research. - 2007. - 53 (3) - Pp. 248-258. - Retrieved from : http://www.education.ualberta.ca/educ/journals/ajer/53\%20files/53(3)files/53(3).html.

6. Schattle H. Global Citizenship in Theory and Practice / H. Schattle. [The Handbook of Practice and Research in Study Abroad : Higher Education and the quest for Global Citizenship]. - New York. - 2009. - Pp. 5-20.

7. Halaktionova I. V. Faktor osvity u formuvanni politychnoi kul'tury hromadianyna demokratychnoi derzhavy [The Factor of Education in Shaping the Political Culture of a Citizen of a Democratic State]/ I. V. Halaktionov // Hromadians'ka osvita v Ukraini : dosvid, poshuky, perspektyvy : materialy konferentsii [Civic Education in Ukraine: Experience, Quest, Perspectives : Conference Materials] / P. P. Motsiiaka, O. V. Zheliba. Nizhyn : NDPU, 2002. - S. 23-26.

8. Goodreau J. Exploring the Dimensions of Global Citizenship / J. Goodreau, D. Holland, D. Montemurro. - 2004. Retrieved from : http://cide.oise.utoronto.ca/projects/globalcitizenship/chap1.pdf.

9. Davies L. Global Citizenship : Abstraction of Framework for Action? Educational Review / L. Davies. - 2006. 58 (1). - Pp. 5-25.

10. Oxfam. Education for Global Citizenship: A Guide for Schools [Oxfam Development Education]. - Oxford, 2006.

11. Crabtree R. D. Theoretical Foundations for International Service-learning / R. D. Crabtree // Michigan Journal of Community Service Learning. - 2008. - 15 (1). - Pp. 18-36. - Retrieved from : http://quod.lib.umich.edu.myaccess.library.utoronto.ca/m/mjcsl/browse.html.

12. Bok S. Common Values / S. Bok. - Columbia, USA (University of Missouri Press), 2002. 
13. Lim C.P. Global Citizenship Education, School Curriculum and Games : Learning Mathematics, English and Science as a Global Citizen / C. P. Lim // Computers \& Education. - 2008. - 51 (3). - Pp. 1073-1093.

14. Munck R. Civic Engagement and Global Citizenship in a University Context: Core Business or Desirable add-on? / R. Munck // Arts and Humanities in Higher Education : An International Journal of Theory, Research and Practice. 2010. - 9 (1). - Pp.31-41.

15. Karlberg M. Discourse, Identity, and Global Citizenship / R. Munck // Peace Review. - 2010. - 20(3). - Pp. 310320.

16. Mayo M. Learning Global Citizenship? Exploring Connections Between the Local and the Global. Education, Citizenship and Social justice / M. Mayo, J. Gaventa, A. Rooke. - 2009. - 4 (2). - Pp. 161-175.

17. Bowden B. The Perils of Global Citizenship. Citizenship Studies / B. Bowden. - 2003. - 7 (3). - Pp. 349-362.

18. Dower N. An Introduction to Global Citizenship / N. Dower. - Edinburgh : Edinburgh University Press, 2003.

19. Betts B. The Challenge of Global Citizenship in Our Schools/B. Betts, 2003. - Retrieved from : http://www.theptc.org/resources/archives.html.

\section{Власенко О. Н. Проблема гражданских ценностей личности в контексте зарубежных концепций гражжданкого общества.}

В статье рассмотрены современные подходы к определению понятия "гражданственность",

"гражданское общество", "гражданские иенности"; выделены основные признаки глобального гражданского общества. Автор исследует теоретические взгляды зарубежных ученых по проблеме гражданственности, системы гражданских иенностей в научной литературе, определяет характерные особенности различных зарубежных научных концепций в контексте проблематики исследования, определяет реализацию гражданских изенностей в современном образовании. В настоящее время общепризнанной есть необходимость гражданского воспитания молодежи, разработки единой государственной политики в области гражданского воспитания, общенациональной цели и гражданской идеологии, которые могли бы консолидировать украинское общзество на основе национальных и гражданских иенностей. Основным звеном реализации системь гражданских иенностей в обществе есть система образования, гуманитарная составляющая которой имеет решающее влияние, как на обеспечение челостности отдельного человека, так и человеческой ичивилизации в целом.

Ключевые слова: гражданское общество, гражданственность, гражданское образование, гражданское воспитание, национальные ценности, гражданские ценности, старшеклассники, образовательное учреждение.

\section{Vlasenko O. M. Problem of Youth' Citizenship Values in the Context of Foreign Concepts of Civil Society.}

The purpose of this study is to examine the role of citizenship education while building the good behavior of citizens in the development of democratic society in Ukraine. The article considers modern approaches to the definition of the concept of citizenship society; to the theory of citizenship values in the context of methodological support of the theory and practice of the modern content of education formation. The author examines the theoretical views of foreign scholars on the problem of citizenship, the system of citizenship values in the scientific literature, determines the characteristics of various foreign scientific concepts in the context of research problems. The author also determines the implementation of citizenship values in modern education.

Creating active citizenship is important to the flourishing of democracy of Ukrainian society, as active citizenship lets the youth defend their democratic rights and responsibilities in the society, play an active part in a democratic life of society. Currently, there is a universally recognized need for youth citizenship education, the development of a unified state policy in the field of citizenship education, a nationwide goal and a citizenship ideology that could consolidate Ukrainian society on the basis of national and citizenship values. The main link in the implementation of the system of citizenship values in society is the system of education, the humanitarian

component of which has a decisive influence both on ensuring the integrity of the individual and human civilization as a whole.

Key words: civil society, citizenship, citizenship education, national values, citizenship values, high school students, educational institution. 